\title{
THE DEVELOPMENT MODEL OF LIVING HOUSES WITH THE MIX USE GENDER-BASED PATTERN (CASE STUDY: KAMPUNG GAJAHMUNGKUR SEMARANG)
}

\author{
Titien Woro MURTINI ${ }^{1, *}$, Arnis Rochma HARANI ${ }^{2}$, Nindita Kresna MURTI ${ }^{3}$, \\ Mustika Kusumaning WARDHANI ${ }^{4}$
}

1, 2, 3, 4 Diponegoro University, Semarang, Indonesia

Received 11 October 2018; accepted 04 January 2019

\begin{abstract}
The existence of Kampung Jajan Pasar in Gajahmungkur Administrative Village, as the village (kampong) in Semarang City that produces traditional snacks for its commodity, has made its people utilize their living houses as a production room to produce food for home industry. Having limited area and facing the demand to extend the rooms for their home industry, these villagers, mostly females, eventually add another use for rooms of their living houses (mix use). These living houses have become the socio-economic places which describe gender equality (for females) in business related to the utilization of rooms using mix use pattern. This research tries to describe the potency of the villagers and their village that has been appointed as the thematic village with topic scope of adaptation resilience at living house towards the production room function. This result is used as the base for the development model of living houses with the gender-based mix use pattern at Kampung Jajan Pasar in Gajahmungkur, Semarang. The data collecting method were literature studies, observations, interviews, and primary and secondary data extraction. The development of the model used graphic design model and the layout design. The given output is a graphic design model of living houses development based on gender and the layout of environmental space as the center of traditional snacks in Semarang City.
\end{abstract}

Keywords: gender, Mix Use pattern, living houses, production rooms, Kampung Jajan Pasar.

\section{Introduction}

Residence or a living house is a representation of space implementation that accommodates socio-cultural activities for the inhabitants. As Wismantara (2009) has pointed out that the occupant's role between men and women has rights and obligations that will affect the use and organization of the space. The attempt to utilize living space by women as an economic space is a manifestation of participation in complementing and supporting family income (Murtini, 2011).

It is similar with Kampung Jajan Gajahmungkur, the business is undertaken by women by utilizing the spaces in the mix-use that exist in the house without changing the room, but only make the arrangement of space and time of use. The use of space in mix use is a situation where space is used in mixed with different functions.

Traditional food production activities of this market is daily conducted by the mothers of Gajahmungkur community. They mostly produce the traditional snacks in resi- dential spaces that use the space in a mixed use. Starting from the production activities that is preparation, processing, packing until the selling is undertaken in each home.

The house found in Kampung Jajan Pasar developed into a productive function. According to Silas in Osman (2012), a space consists of 3 criteria, mixed type, balanced type, separate type. The existence of a productive house reinforces the function of the house for human life, that is as a product of human results that support the daily life associated with the economy. In addition, the role of women as the users of the production room illustrates the fact of gender equality as the actors who form the economic space in a place (a house). This indicates that the actors (gender) affect the economic space in the formation of residential space in Kampung Jajanan Pasar Gajahmungkur.

J. Silas (1999) affirms that the Home Based Enterprises (HBEs) are oriented towards the 3 (three) key elements / stages which become the core of HBEs activities: 1). Preparation and storage of raw materials, 2) Production process, 3) Storage results. These three stages can serve as a

${ }^{*}$ Corresponding author. E-mail: titien_wm@yahoo.com 
benchmark in looking at the interactions between HBEs (especially production HBEs) with the household life.

By utilizing residential space as a business space and production (mix use), it requires space and particular model of production business spaces development which able to accommodate activities well based on gender (women). Therefore, it needs research on Development of Living Houses with Gender Based Mix Use Pattern In Kampung Jajan Pasar Gajahmungkur Semarang.

\section{Methods}

The research method used is qualitative research with phenomenology paradigm. This method is an attempt to understand the meaning of events and their relation to the ordinary people in certain situations (Moleong, 2001). Researchers strives to reveal the meaning of the human life behavior phenomenon, both human capacity as individuals, groups and communities in Kampung Jajan Pasar Gajahmungkur, Semarang. Data collection was undertaken by using two methods, namely primary and secondary data collection methods.

Primary data collection method aims to determine the use of residential space associated with the role of gender in the production activities of traditional food through interview techniques and field observation. Interview is conducted to the community who conduct traditional food production activities by utilizing the living house. While field observation assits to gain a clearer portrayal about the production activity of traditional food and the area of study. Meanwhile, the secondary data collection method is undertaken by studying the literature and document review through the study of the study area map, the demography and so on from the survey results in related institutions, namely Gajahmungkur administrative village and hamlet IX, Gajahmungkur.

Sampling is conducted through non-random sampling technique that begins with the determination of the sam- ple by the informant's information towards the traditional food production houses in Gajahmungkur.

\section{Discussion}

The area of study in this research is located in Kampung Jajan Pasar, Gajahmungkur Village, Semarang. Gajahmungkur administrative village belongs to Central Semarang area located in parts of the city (BWK) II, Semarang (see Figure 1). According to detailed spatial plans (RDTR) of Semarang, Indonesia, parts of the city (BWK) II area is designated for settlement and has function as city service center and center of trade and service activities. The administrative boundaries of Kampung Jajan Pasar, Gajahmungkur, Semarang are:

- North: Kaligarang Street

- East: S. Parman Street

- South: Papandayan Street

- West : Kelud Raya Street

Gajahmungkur Administrative Village consists of 9 RW and 89 RT. Based on Gajahmungkur Village Monograph data in 2017 , the population is 15,760 people with 4,909 families and 5.744 people $/ \mathrm{km}^{2}$ population density.

In Gajahmungkur Administrative Village, there are many living houses which have double function, that is as residence and business place. What makes it interesting is that the community concentrates on the market snacks (traditional food). And they are the suppliers of market snack in Semarang City. Market snack or traditional food they produced are: Klepon, Sentiling, Boiled Nuts, Peyek, Boiled Banana, various fried foods, as well as food typical of Semarang, namely Wingko Babat, Bakpia Pathok. The producer of traditional snacks in the village of Gajahmungkur dominated in hamlet IX. hamlet IX residents are quite active residents compared to other hamlets in Gajahmungkur administrative village. This activity is demonstrated by many community activities and training conducted at hamlet IX and the interest of the community itself. This is
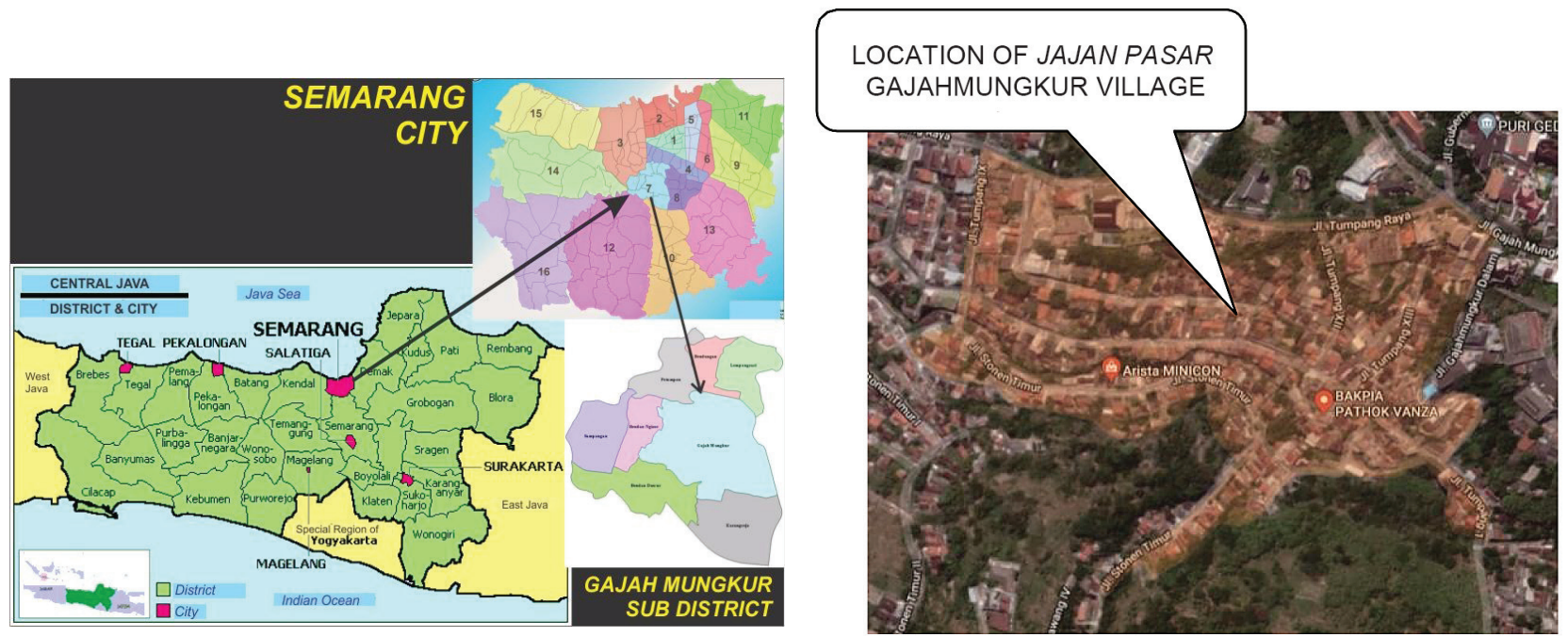

Figure 1. Location of Gajah mungkur Administrative Village and Jajan Pasar Village area 
supported by the training activities of the previous small food production, so that the community already has a skill provision for the production of snack business.

Jajan Pasar Tematic Village (see Figure 2) is a village that has potential as a producer of traditional food (market snack). Therefore, by the potential that existed in 2015 by the Government of Semarang hamlet 9 urban village of Gajahmungkur was designated becoming Jajan Pasar Tematic Village as botton up. The result of traditional food production in Jajan Pasar village is divided into 2 (two) groups, namely production group with fixed distribution and food production group by order.

a. Snack Production with Fixed Distribution

In Jajan Pasar Village, there are 3 (three) snack market businesses with fixed capital and distribution. From informant's information (Chairman of hamlet Mr. Dwiyanto), these three snack products have a fixed supplier place in Semarang, Yogyakarta, Magelang, and Pantura. From the results of information from the owners, Mrs. Yoko,
Mrs. Saudiah, and Mrs. Della (housewife), they have permanent employees between 3-5 people working from morning to evening to produce food.

Here is the location of fixed production house in Jajan Pasar Gajahmungkur Village;

Traditional food (snack) production house in Jajan Pasar Gajahmungkur Village has background story among the owners. Initially, the owner of Bakpia's production of Mrs. Yoko, works at Bakpia business house production Mrs. Saudiah and Mrs. Yoko with Mrs. Della have family ties. So that production activities in Jajan Pasar Village mutually could support each other and well develop.

Case 1: Mrs. Yoko's House

Mrs. Yoko's Wingko production house in yellow zone is the use of separated production room with residential, that is in the process of production and ingredients processing to be Wingko (see Figure 3). While in the red zone is a production space in the mix use that is on the use of living room with display space and living room used together with the wrap-

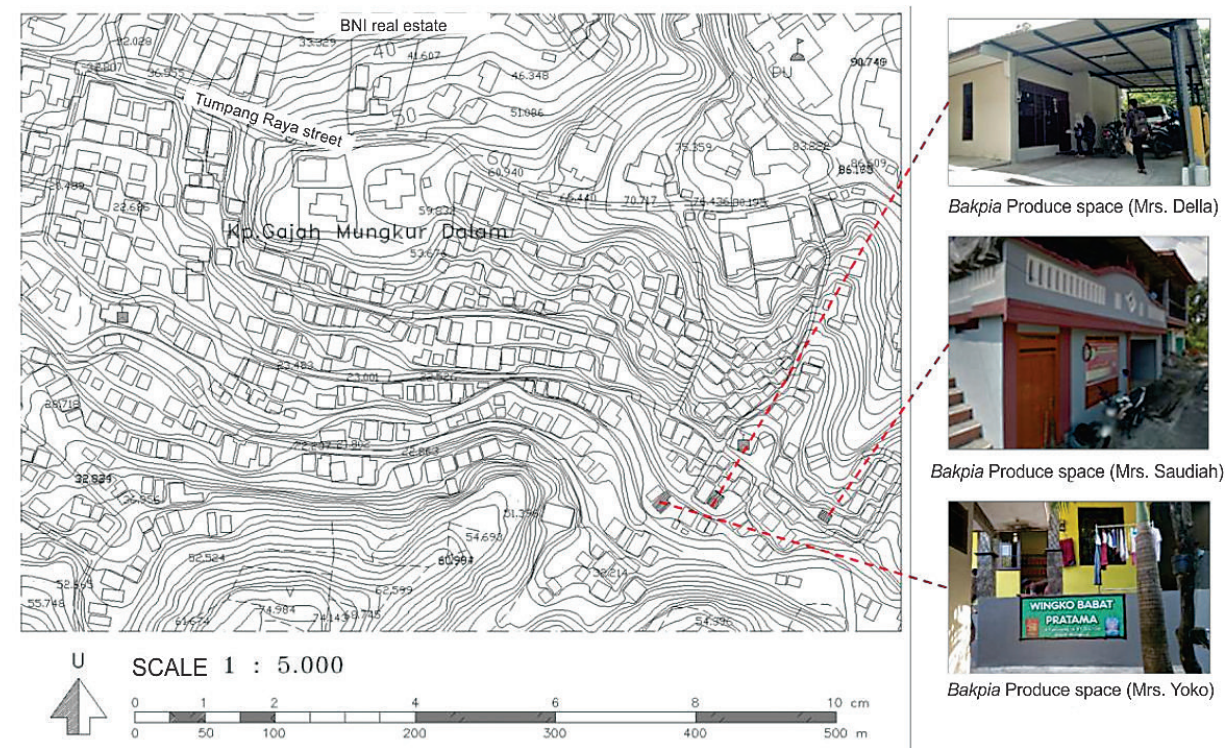

Figure 2. Location of "Jajan Pasar" (traditional snack) Production House in hamlet IX Gajahmungkur Administrative Village

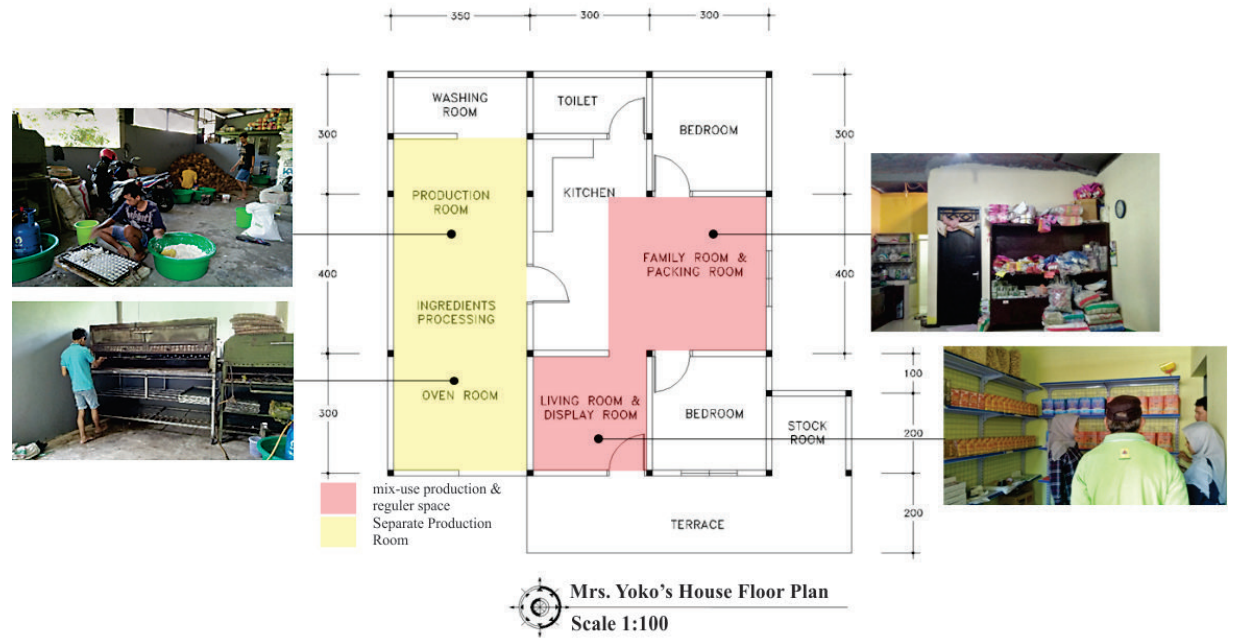

Figure 3. Mix-use production space \& regular space in Mrs Yoko's house (Case 1) 
ping room. The organization placement of this space is a tolerance made by the role of members of the house, especially women as business controllers and men as head of the family.

Case 2: Mrs. Dilla's House

In the use of living space in Mrs. Dilla's Bakpia production house (see Figure 4), as a whole is, the use of space in mix-use where the living room used along with the display room, living room which is in mix-use space used as a wrapping room and roasting with other functions as a family room. Then the kitchen space is used simultaneously with the production process of ingredients processing room. Spaces that are not used in a mix use are on the use of the private space; the bedroom.
Case 3: Mrs. Saudiah's House

Wingko production house of Mrs. Saudiah has 2 (two) residential floors, on 1st floor (first) with yellow zone used as separated production room with residence (core). On the1st floor is used as warehouse ingredients and wingko roasting production, while on the 2 nd floor house is used as residential space which is used as a mix of production space, the spaces used in this mixture is the terrace which is also used as a wrapping room, living room used as display room of the product, and the family room that is used as the material process space (see Figure 5).

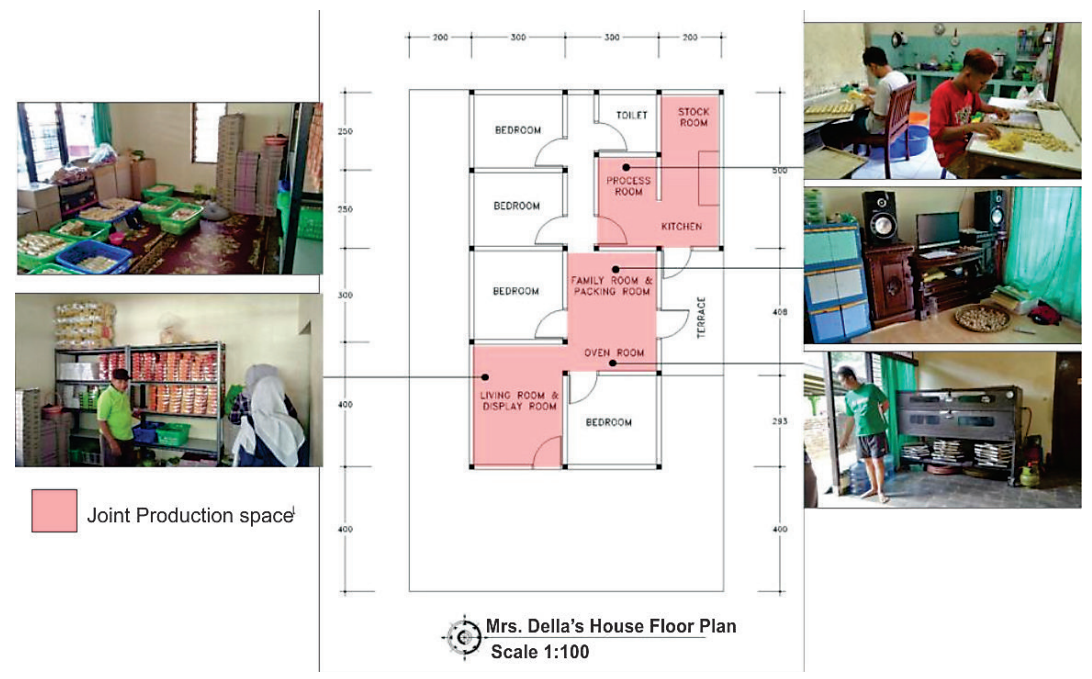

Figure 4. Joint Production space in Mrs Dilla's house (Case 2)
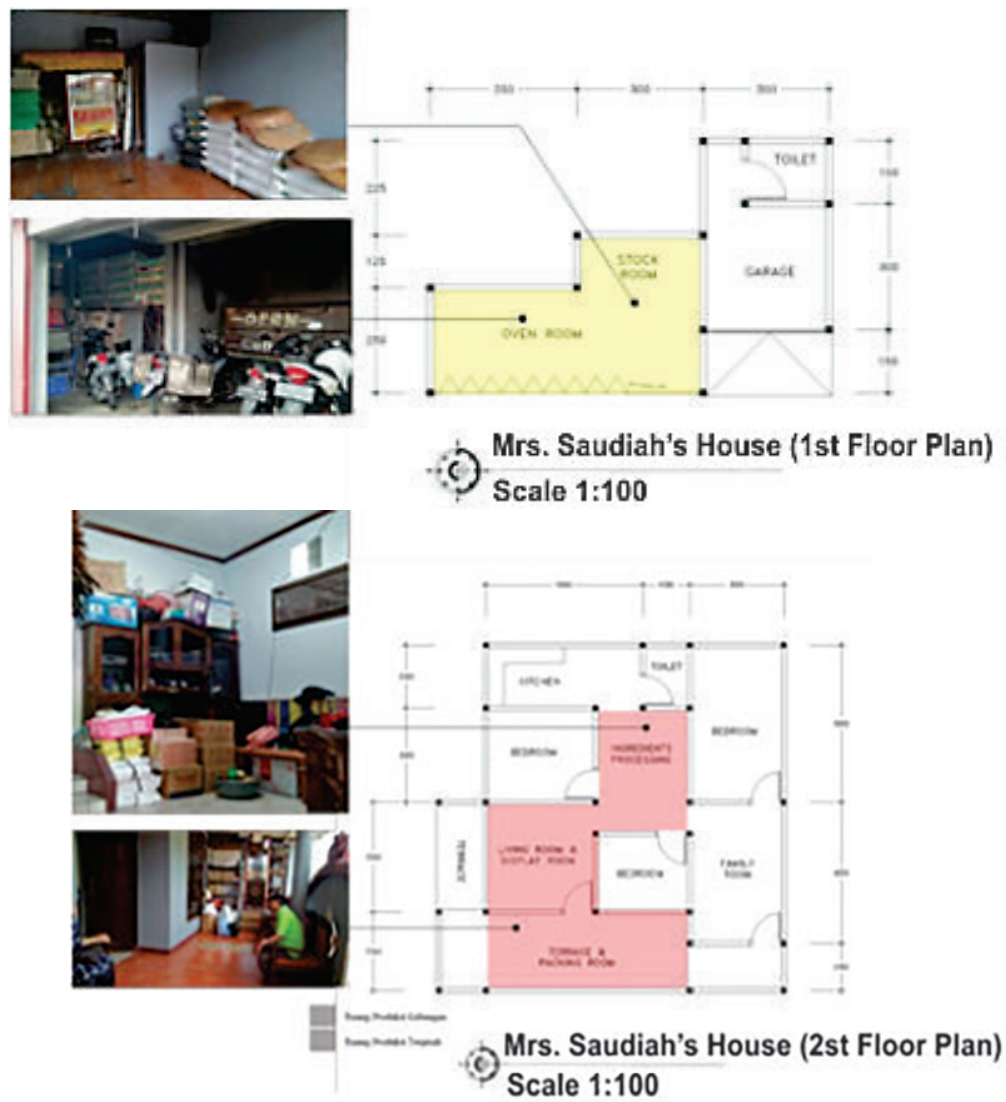

Figure 5. Production space and residential space separated in Mrs. Saudiah house (Case 3) 
b. Traditional food made by order

Production activities of the second group traditional food will be present when there is an order, then coordinator contacts other producer to make snacks, production activities are undertaken in each home then collected and decorated at house of the coordinator. And this production activity can only be found on certain days.

Case 4: Mrs. Farida's House

Mrs Faridah on average receives orders 2-3 times a week and conducts Jajan Pasar production activities in the morning and evening. The room in Mix-use with a residence is the kitchen and living room to place the market snacks. Market snacks made are: Dadar Gulung, Resoles, Lemper, and bread. Red space is a kitchen in mix use by gender as a Jajan Pasar producer (see Figure 6).

\section{Case 5: Mrs. Indah's House}

Mrs. Indah has been around for 3-4 years in Jajanan Pasar production. Within a week Mrs Indah produced 50-100 piece / type of Jajanan Pasar and was done from $4 \mathrm{pm}$ - finished. The room in Mix Use is the kitchen and family room, this is because the kitchen area is quite wide and the family room is close to the kitchen so it is more efficient (see Figure 7). Market snacks produced by Ibu Indah are: onde-onde, amris and naga sari. The activities of selling and buying in traditional markets are increased by interaction between buyers and sellers and by the tolerance attitude among sellers (Murtini, 2017).

Case 6: Mrs. Novia's House

Approximately \pm 1 year Mrs. Novia pursues Jajanan Pasar production. Jajanan Pasar produced by Mrs. Novia

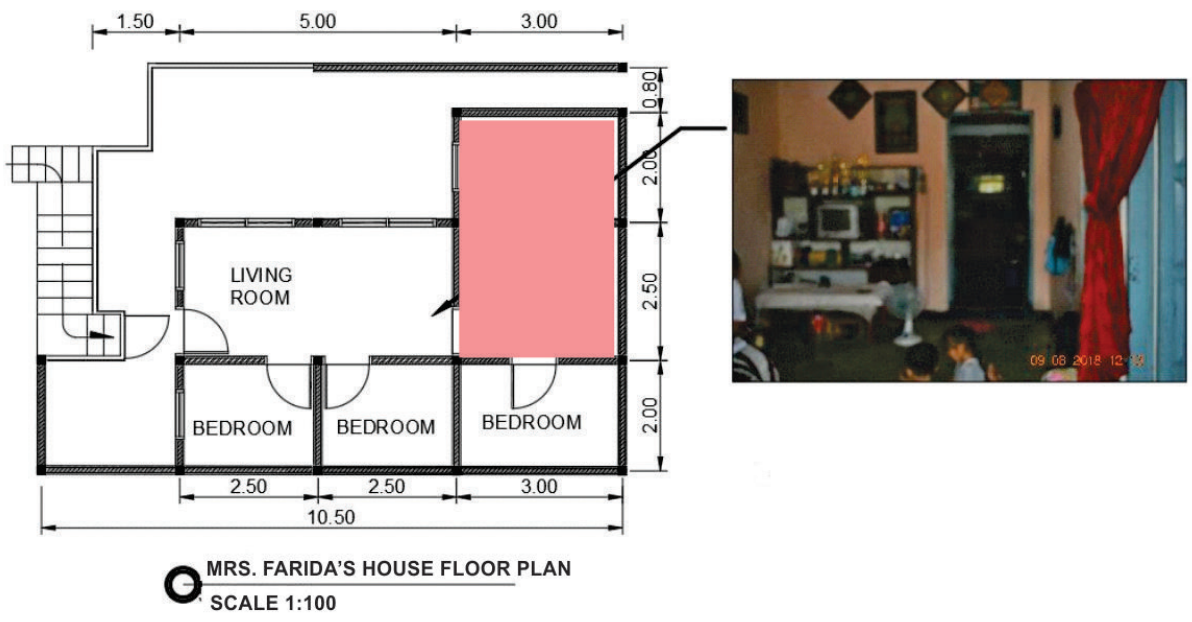

Figure 6. Red Space as a mix-use space used by Gender in Mrs. Faridah's house (Case 4)

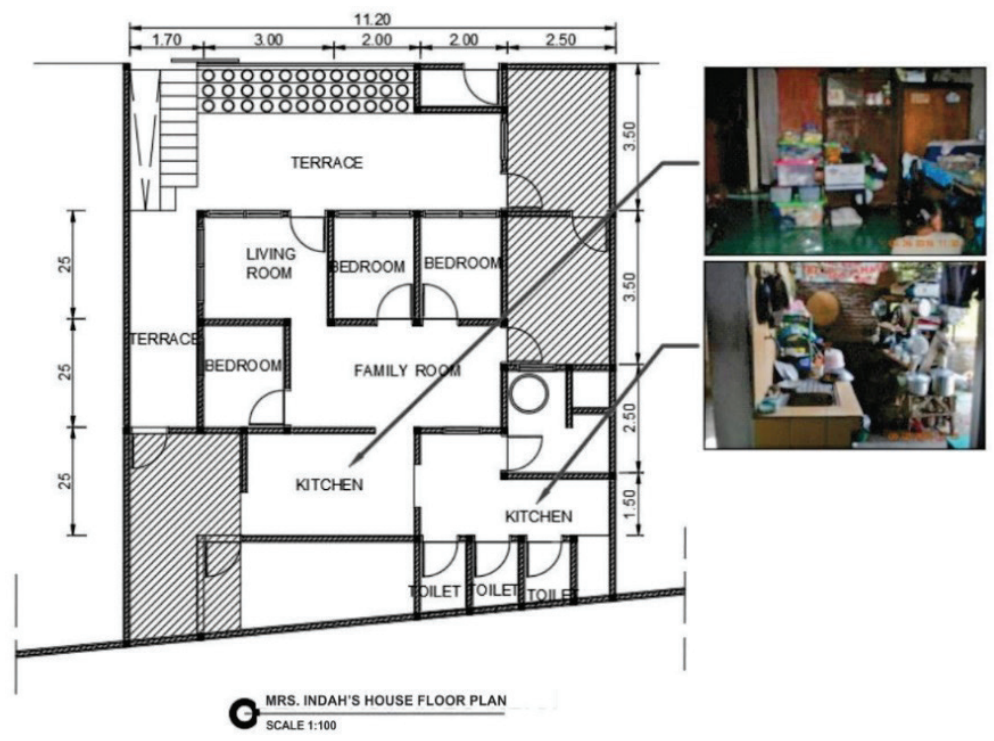

Figure 7. Mix-use space is in the kitchen and family room in Mrs. Indah house (Case 5) 


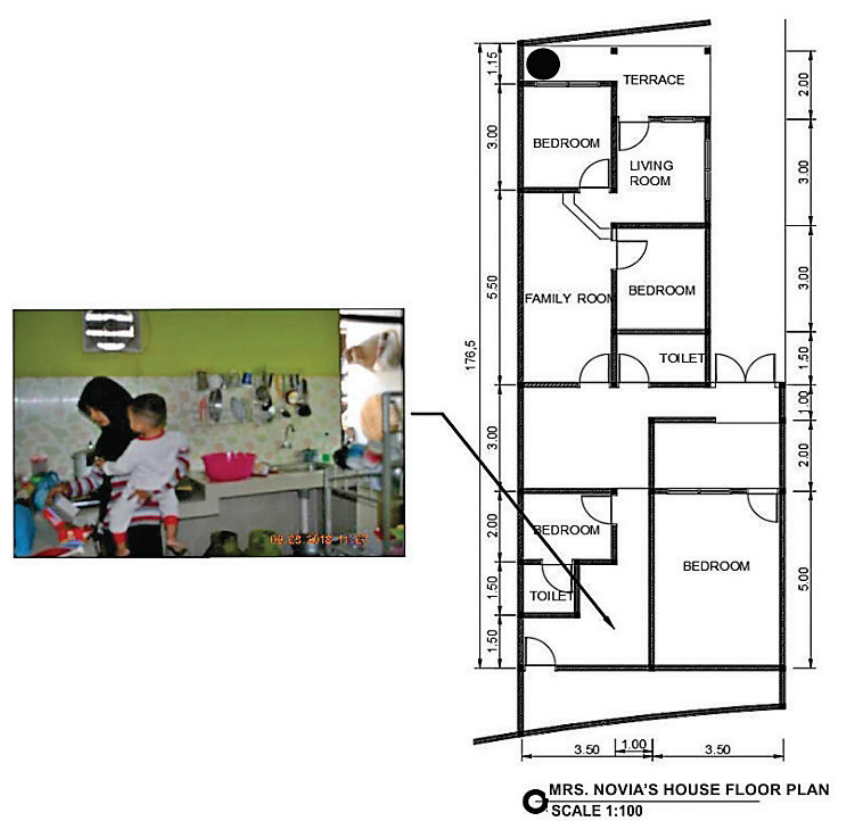

Figure 8. Kitchen as mix-use space in Mrs. Novia's house (Case 6)

are: Serabi Solo, Klepon Pumpkin, Getuk, Cassava Cheese, Makaron Seotel, and Pukis Labu. In one production Mrs Novia produced 100 piece / type of Jajanan Pasar and made at $10.00 \mathrm{am}$ or $17.00 \mathrm{pm}$. The room in Mix Use is the kitchen, this is because the process of cooking and storage for jajanan pasar are in the kitchen (see Figure 8).

Case 7: Mrs. Markonah's House

Mrs. Markonah's house is located at Tumpang street I / No. III and already \pm 10 years of producing Jajanan Pasar in the week, Ms. Markonah gets \pm 2 orders, in one production produces $30-50$ seeds or according to consumer orders. The rooms that are in Mix Use with residential houses are the living Room and the kitchen (see Figure 9). Market snacks made by Ms Markonah are: Putu Ayu, Bolu Kukus, and Onion stick.

From the 7 cases described above, the following table uses gender space as a mix use space (see Table 1):

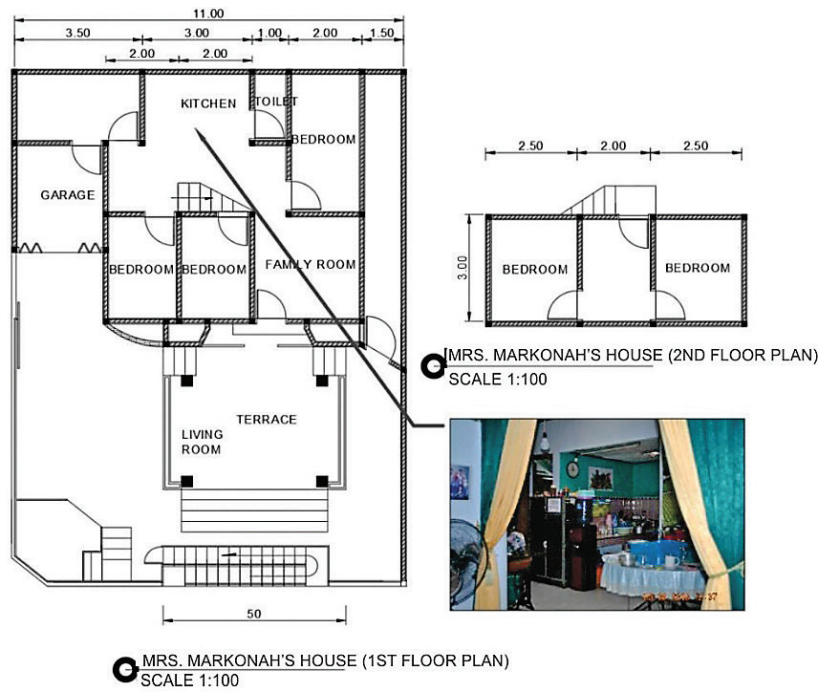

Figure 9. Living room and Kitchen as mix-use production space in Mrs. Markonah's house (Case 7)

Characteristics of the house living traditional food production in Gajahmungkur

From the results obtained, the use of space in the use of mixed use in Jajan Pasar village uses the function of the terrace, living room, family room, and kitchen. These spaces are known to have spaces reserved for women and men. If the gender spaces used in mix use are usually in the service room, because of their proximity to the women's power space (Murtini, 2018). But in the use of Jajan Pasar's production house space, the use of mixed space is in the area of tolerance between the role of women (as business controller) and men (as head of the family). So that the mix between gender roles (women) is able to balance the role of men in tolerance of the use of residential space.

Various human activities including business activities require space as media. Human activity can create a space to meet the needs of the activity itself. It is understandable

Table 1. Use of mixed use space

\begin{tabular}{|c|c|c|c|}
\hline No & Case & The room used & Reason \\
\hline 1 & Case 1 & Family Room, Living Room & Practical and wide room \\
\hline 2 & Case 2 & Kitchen, Family Room, Living Room & Practical and wide room \\
\hline 3 & Case 3 & Family Room, Living Room, Terrace & Practical and wide room \\
\hline 4 & Case 4 & Kitchen, Living Room & Practical and wide room \\
\hline 5 & Case 5 & Kitchen, Living Room & $\begin{array}{l}\text { The kitchen room is wider, the living room is close to } \\
\text { the kitchen and is practical }\end{array}$ \\
\hline 6 & Case 6 & Kitchen, & Practical \\
\hline 7 & Case 7 & Kitchen, Living Room & $\begin{array}{l}\text { Practical and the living room is close to the kitchen and is } \\
\text { practical }\end{array}$ \\
\hline
\end{tabular}


that in the architectural study of a space will always be related to human and human activities as the perpetrator of the activity. If it is linked to a survey conducted in the field there is a result if the building of a separated production house with a residential house is expanding vertically or horizontally. It is used to improve business results due to inadequate residential spaces.

Traditional food business production conducted by Jajan Pasar Thematic Village, has made the local community use their living space as production room and living room. The existence of two activities, namely household activity and business activity in a residential area create a culture of tolerance and transformation of living space activity. While Habraken (1988) stated that socio-cultural and economic factors as factors that affect changes in occupancy. This is related to the utilization of space, especially space for business needs, mainly when it is associated with the type of HBEs itself, that is a type of traditional food (snack) production business which certainly has a different space needs than other HBEs so that the transformation will appear to the activities of space residents as an adaptation resilience effort.

\section{Conclusions}

Production activities of traditional snack business in Hamlet IX Jajan Pasar Thematic Village Gajahmungkur is influenced by the role of women as the main actors. The spaces used as production sites are the tolerance space that men give to their wives in support of HBEs (Home Based Enterprises) activities using mixed space patterns. Spaces used in the mix use in the production of traditional snack is on the terrace, living room, family room, and kitchen. Given the shared space with two different activities, household activities and business activities within a home sphere create a culture of tolerance and transformation of living space activity.

The use of the outer space (roadside) as non-permanent stall brings tolerance and understanding among sellers. It shows that even though the stalls are limited, the tolerance among sellers still exists. These female sellers are naturally meek and know more about economic activities that can be seen from how they sell, attract attention (marketing), and bargain. The activities of selling and buying in traditional markets are increased by interaction between buyers and sellers and by the tolerance attitude among sellers. Spaces in house are used by gender as are using existing living space in mixed use.
Production activities are carried out by alternating time with daily activities.

In addition, as the activity of thematic village has a positive role to the economic development of the local community, so as an effort to develop Jajan Pasar village in Gajahmungkur need to build a traditional food shackover for distributing the production activities of the Jajan Pasar Gajahmungkur village community. The shelter house present is expected to increase selling results and facilitate the selling to lift Jajan Pasar Thematic village.

\section{Acknowledgements}

Acknowledgment of the authors convey to the chairman of Hamlet IX, Mr. Dwiyanto who has provided data information and took time to accompany the survey, as well as Mrs. Yoko, Mrs. Saudiah, and Mrs. Della as the owner of the traditional snack production business that has the pleasure in conducting interviews.

\section{References}

Habraken, N. J. (1988). Type as a social agreement. Paper Asian Congress of Architects Seoul.

Murtini, T. W. (2011). Peran Perempuan Dalam Pemanfaatan Ruang Pada Rumah Tinggal Sebagai Ruang Ekonomi [The Role of Women in the use of space in residential houses as economic space]. Retrieved from http://eprints.undip. ac.id/29293/1/Peran_Perempuan_Dalam_Pemanfaatan_Ruang_Pada_Rumah_Tinggal_Sebagai_Ruang_Ekonomi.pdf

Murtini, T. W. (2017). Relation between gender and economic space in traditional market at Pasar Gang Baru Semarang. Asian Journal of Humanities and Social Studies (ISSN: 2321 2799), 05(05), October 2017.

Murtini, T. W. (2018). Mix use pattern of gender basis Batik Craftsman Residential Houses in Babagan Village. Jurnal Tataloka, 20(2), 113-123. https://doi.org/10.14710/tataloka.20.2.113-123

Moleong, L. J. (2001). Metodologi Penelitian Kualitatif [Qualitative Research Methodology]. Bandung: Remaja Rosdakarya.

Osman, W. W. dan S. A. (2012). Rumah Produktif: Sebagai Tempat Tinggal dan Tempat Bekerja di Permukiman Komunitas Pengrajin Emas [Productive House: As a Residence and Workplace in the Community of Gold Craftsmen Settlements]. Prosiding Jurusan Arsitektur, 6, 1-10. Makassar: Universitas Hasanuddin.

Silas, J. (1999). Home based enterprises. Seminar Lecture Materials, Settlements of the city and Environment. Surabaya: Pasca Sarjana Institut Teknologi Sepuluh Nopember.

Wismantara, P. P. ( 2009). Gender Politics at Taneyan Settlement Lanjhang Sumenep. Jurnal Kesetaraan dan Keadilan Gender, IV, 2 page, 185-198. 